\title{
Avaliação microbiológica e teste de sensibilidade in vitro de bactérias isoladas do útero de éguas da raça Crioula
}

Rafael dos Santos Bandeira ${ }^{[]^{*}}$, Julia Thomasini[ib], Bruna Spadotto ${ }^{[b]}$, Gabriela Lorenzet ${ }^{[b]}$, Gabriel Victoria Martins ${ }^{[b]}$, Guilherme Novello $0^{[b]}$, Raqueli Teresinha Françą ${ }^{[b]}$, Fernando Paixão Lisboa ${ }^{[b]}$

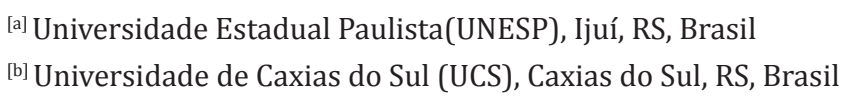

*Autor correspondente

e-mail: rafa.bandeira@hotmail.com

\section{Resumo}

A endometrite é uma das principais causas de infertilidade em éguas, gerando perdas econômicas, descarte de animais, abortos e mortes embrionárias. Este trabalho tem como objetivo identificar os principais agentes bacterianos isolados do útero de éguas da raça Crioula e testar a sensibilidade in vitro dos mesmos. Foram coletadas amostras de 74 éguas que apresentavam sinais de alterações reprodutivas, como acúmulo de líquido uterino, presença de secreção vulvar e/ou sucessivos diagnósticos negativos. Os animais são provenientes de propriedades localizadas no estado do Rio Grande do Sul e as amostras foram colhidas durante o período reprodutivo 2014/2015 e 2015/2016. A colheita do material foi realizada no estro com auxílio de Swab protegido Provar ${ }^{\circledR}$, sendo acondicionado em meio Stuart e enviado ao laboratório imediatamente em seguida. As amostras foram semeadas em meios ágar sangue (Sangue equino desfibrinado 5\%) e Macconkey, sendo mantidas a 37ํㅡ por 24 horas. Após isolamento, as bactérias foram identificadas por métodos bioquímicos. Observou-se isolamento microbiano em 63,5\% (47) das amostras, sendo 36,5\% (27) negativos. Isolou-se com maior frequência: Escherichia coli, 22 (46,8 \%); seguido de Klebsiella, 12 (25,54 \%); Staphylococcus sp., 5 (10,64 \%); Staphylococcus aureus, 2 (4,25\%); Proteus sp., 2 (4,25\%); Enterobacter, 1 (2,13\%); Enterococcus, 1 (2,13\%); Streptococcus $\beta$-hemolítico, 1 (2,13\%). Apenas um dos animais testados apresentou crescimento fúngico (Candida sp.). 0 perfil de sensibilidade microbiana in vitro assinalou como mais efetivos a Amicacina 89\% (32/36), Enrofloxacina 76\% (19/25), Gentamicina 72,7\% (32/44), Ceftriaxona 71\% (29/41) e Sulfametoxazol + Trimetropim 69\% (29/42). Alguns antimicrobianos testados apresentaram $100 \%$ de sensibilidade, porém o número de testados foi relativamente baixo, por isso optou-se pela não utilização dos dados. Dentre os antimicrobianos que apresentaram maior frequência de resistência destaca-se a Ampicilina 77\% (23/30), Penicilina 64\% (07/11), Sulfametoxazol + Trimetropim 
29\% (12/42), Gentamicina 25\% (11/44), Ceftriaxona 17\% (07/41), Amicacina 11\% (04/36), Enrofloxacina $8 \%(02 / 25)$. A resistência bacteriana e o isolamento de agentes fúngicos em endometrites em éguas podem decorrer do uso indevido de antimicrobianos, tanto pelo uso parenteral como em infusões uterinas. Estes animais utilizados no experimento não têm o diagnóstico de endometrite, já que para a confirmação seria necessário a correlação com a citologia endometrial. No entanto, tais achados comprovam a importância da realização de antibiogramas para a realização de tratamentos reprodutivos, visto que muitos dos agentes isolados apresentam resistência a antibióticos amplamente utilizados na rotina.

Palavras-chave: Égua. Endometrite. Resistência bacteriana. 